\title{
URETHRAL AND VAGINAL INFECTIONS, AGE OF PATIENTS AND STATE OF THE PELVIC FLOOR IN THE AETIOLOGY OF THE IRRITATIVE SYMPTOMS OF THE LOWER URINARY TRACT IN WOMEN.
}

\author{
Carlo Vecchioli Scaldazza' and Carolina Morosetti².
}

Division of Urology' and Pathological Anatomy and Clinical Research². Jesi Hospital. Jesi. Italy.

\begin{abstract}
Summary.- OBJECTIVES: The aim of this study was to evaluate the importance of a) urethral and/or vaginal infections caused by common germs or Mycoplasmas, Chlamydia, Candida; b) age of patients; cl pelvic floor disorders in the development of irritative urinary symptoms in women.
\end{abstract}

METHODS: 77 consecutive abacteriuric symptomatic female patients were compared with 55 asymptomatic women. A detailed micturition history and a genitourinary physical examination were performed. Urine samples as well as vaginal and urethral swabs were taken for cultures.

RESULTS: No statistical difference was found between the two groups regarding both urethral and/or vaginal infections and pelvic floor disorders. Whereas a significant statistical difference was found in the age of the patients. In the symptomatic group the women were older than in the asymptomatic group.
CONCLUSIONS: The results of this study confirm that ageing is a very important cause in the development of the lower urinary tract symptoms in women.

Keywords: Ageing. Bladder diseases. Urethral infections. Vaginal infections. Vaginal prolapse.

Resumen.- OBJETIVO: El objetivo del estudio es la evaluación de la importancia de al las infecciones uretrales y/o vaginales producidas por gérmenes comunes o micoplasmas, clamidias y cándidas; bl la edad de las pacientes; y c) las alteraciones del suelo pélvico, en el desarrollo de síntomas urinarios irritativos en mujeres.

MÉTODOS: Se compararon 77 pacientes sintomáticas sin bacteriuria con cincuenta y cinco pacientes asintomáticas. Se realizaron historia clínica del componente miccional y exploración física genitourinaria. Se tomaron muestras de orina, uretra y vagina para cultivo.

RESULTADOS: No se encontraron diferencias estadísticas entre los grupos ni en infecciones uretrales y/o vaginales ni en alteraciones del suelo pélvico. Sin embargo se encontró una diferencia estadísticamente significativa en la edad. En el grupo sintomático las pacientes eran más mayores que en el grupo ha sintomático.

CONCLUSIONES: Los resultados de este estudio confirman que el envejecimiento es una causa muy importante de desarrollo de síntomas del tracto urinario inferior en la mujer.

Palabras clave: Envejecimiento. Enfermedades de la vejiga. Infecciones uretrales. Infecciones vaginales. Prolapso vaginal. 


\section{INTRODUCTION}

Irritative urinary symptoms (frequency, urgency, nocturia, urge incontinence) in women may have many different causes. Several studies have shown that in approximately half of the patients, the symptoms are due to bacterial cystitis caused by well-known urinary pathogens such as Escherichia Coli $(1,2)$. However frequency and urgency are also described in women who have not significant bacterial growth in urine culture (3). Some authors believe there are several causes (4) and many urologists believe that sphincter spasms (5) or anatomical variations of the genitalia (6) are of importance.

The aim of this study is to determine the relationship of irritative bladder symptoms to 1) urethral and/ or vaginal infections caused by both common germs and Chlamydia trachomatis, Mycoplasmas (Mycoplasma hominis, Ureaplasma urealyticum), Candida; to 2) patients' age and to 3) pelvic floor disorders.

\section{MATERIALS AND METHODS}

77 consecutive abacteriuric female patients who were referred to the department over a 12 month period with irritative bladder symptoms were compared with 55 similar control women who were referred in the same period with urogynecologycal diseases without irritative urinary symptoms.

A detailed micturition history was obtained from patients who then underwent a genitourinary physical examination.
Both symptomatic and asymptomatic women filled out a questionnaire on previous urinary-tract symptoms.

Prolapses were evaluated and graded according to the halfway system classification of Baden and Walker with the patients in the lithotomy position and under maximum straining effort. Urine samples as well as vaginal and urethral swabs were taken for cultures.

The diagnosis of Candida was based on the presence of yeast cells and pseudohyphae in Gram stained vaginal smears.

The vaginal secretions were cultured for 72 hours at $37^{\circ} \mathrm{C}$ on Sabouraud agar.

In Chlamydial infection vaginal swabs were sent to the laboratory and processed using polymerase chain reaction (PCR).

In Mycoplasmas infection vaginal swabs were sent to the laboratory and then inoculated into a broth containing urea ( $U$. urealyticum), and into a broth containing arginine dihydrochloride (M. hominis).

In bacterial vaginosis swabs were cultured aerobically and anaerobically on blood, chocolate, and MacConkey agars, and on Gardnerella selective medium. Gram stained smears were examined too.

Patients with neurological disease, pregnant women, urinary tract tuberculosis, diabetes, bladder or pelvic tumors, pelvic radiotherapy, bladder stones and urinary tract infections were excluded.

TABLE I. INFECTIONS: ISOLATED GERMS (COMMON GERMS).

\begin{tabular}{|l|l|}
\hline GROUP A & GROUP B \\
\hline Enterococcus foecalis* & Enterococcus foecalis* \\
Escherichia coli * & Streptococcus agalactiae \\
Streptococcus agalactiae & Escherichia coli * \\
Proteus mirabilis & Proteus mirabilis \\
Gardnerella vaginalis & Klebsiella pneumoniae \\
Klebsiella pneumoniae & Staphylococcus haemoliticus \\
Citrobacter diversus & \\
Staphylococcus epidermidis & \\
\hline
\end{tabular}

* Germs isolated both in urethra and vagina 

software.

Statistical analysis was performed using analytical

Statistical significances were calculated in all but age parameters using the Chi-square test with a $p$ value $<0.05$ considered to be significant. The parameter "age" was calculated using the two-sample Wilcoxon test with a $p$ value $<0.05$ considered to reflect a statistically significant correlation.

\section{RESULTS}

In Table I, we reported the common germs discovered in urethral and vaginal swabs. Mycoplasmas, Chlamydia and Candida were not included whereas Lactobacilli were considered not pathogenous and were not included either.

A comparison was made between group $A$ and $B$ regarding the presence of common germs.

No statistical difference was found $(p=$ 0.601442) (Table II).

Then, a comparison was made between the two groups regarding the presence of Mycoplasmas,
Chlamydia and Candida in urethral and vaginal secretions.

Mycoplasmas, Chlamydia and Candida were evaluated together in a single group first, then Mycoplasmas (Ureaplasma urealiticum and Mycoplasma Hominis) were evaluated separately.

Also in this case no difference was found $(p=$ $0.210703 ; p=0.711439$ respectively) (Table II).

Then, we evaluated pelvic floor disorders.

Patients were subdivided into four different groups.

a) patients with or without prolapse;

b) patients with anterior vaginal wall prolapse;

c) patients with prolapse of the apical segment

d) patients with posterior vaginal wall prolapse.

No statistical difference was observed in all comparisons performed ( $p=0.882701 ; p=0.976057$; $p=0115037 ; p=0.486834$ respectively) (Table III).

Then, we evaluated the correlation between urinary symptoms and age of patients.

In group A patients were older than in group $B$, with a significant statistical difference $(p=0.01203)$ (Table IV).

TABLE II. URETHRAL AND VAGINAL INFECTIONS.

\begin{tabular}{|c|c|c|c|}
\hline & GROUP A & & GROUP B \\
\hline $\begin{array}{l}\text { Common germs * } \\
\text { GROUP A vs B }\end{array}$ & $51 / 77$ & $p=0.601442$ & $34 / 55$ \\
\hline $\begin{array}{l}\text { Mycoplasmas* * } \\
\text { GROUP A vs B }\end{array}$ & $11(1) / 77$ & $p=0.210703$ & $4(0) / 55$ \\
\hline Candida & $4 / 77$ & & $4 / 55$ \\
\hline Chlamydia & $1 / 77$ & & $2 / 55$ \\
\hline $\begin{array}{l}\begin{array}{l}\text { Mycoplasmas } \\
\text { Chlamydia }\end{array} \\
\text { GROUP A vs B }\end{array}$ & $16 / 77$ & $p=0.711439$ & $10 / 55$ \\
\hline
\end{tabular}

* Lactobacilli are not included

* * Mycoplasmas include both Ureaplasma urealyticum and (I Mycoplasma hominis 


\section{DISCUSSION}

Mycoplasma hominis and Ureaplasma urealyticum are the most frequently isolated Mycoplasmas from the human genital tract. They are ubiquitous resulting in colonisation of the genitalia by sexual contact (7). The first large prospective study to investigate the role of $M$. hominis as a vaginal pathogen in adults was performed by Arya et al. (7). Its isolation rates and colony counts among women with symptoms were not significantly different from women without symptoms.

In 1983 Stamm et al. (8) in an assessment of the possible etiologic role of $M$. hominis and $U$. urealyticum in the acute urethral syndrome (AUS) in women, compared urine, urethral and vaginal swabs of 79 women with AUS with those of 66 asymptomatic volunteers and they were unable to find evidence suggesting that $M$. hominis caused AUS. Their data suggested a possible etiologic role for $U$. urealyticum in some women with lower urinary tract symptoms but certainly did not prove such a role.

Bump et al. in 1985 (9) valued 86 women with chronic urologic complaints and negative bacterial urine cultures. No significant difference in urologic symptoms between $U$. urealyticum urethral culture-positive and culture-negative patients was found.
Whereas an evident correlation was found between $U$. urealyticum vaginosis and premature rupture of membranes in pregnant women, contributing to a premature start of labour (10).

Chlamydia trachomatis is not a common cause of chronic lower urinary tract complaints or dysfunctions (9) but it is one of the most common sexually transmitted bacterial diseases.

Farley et al. (1 1) estimated that the prevalence of Chlamydial infection was $10.1 \%$ and that $77 \%$ of all cases were never symptomatic. No difference was found in the incidence of infection by $\mathrm{C}$. trachomatis in women with lower urinary tract symptoms in a controlled study by Gillespie et al. (12).

Furthermore most infections caused by $C$. trachomatis being asymptomatic, result in a large reservoir of unrecognised, infected individuals capable of transmitting the infection to sexual partners (13).

Candidiasis is another important genital infection in women. Approximately 13 million cases of vulvovaginal candidiasis occur annually in the United States (14).

A significant percentage of women with this complaint, will experience subsequent episodes, and

TABLE III. VAGINAL WALL PROLAPSE.

\begin{tabular}{|c|c|c|c|}
\hline & GROUP A & & GROUP B \\
\hline Patients with prolapse & $36 / 77$ & & $25 / 55$ \\
\hline GROUP A vs B & & $p=0.882701$ & \\
\hline Anterior prolapse & $31 / 77$ & & $22 / 55$ \\
\hline | and || degree prolapse & $31 / 77$ & & $17 / 55$ \\
\hline III and IV degree prolapse & $0 / 77$ & & $5 / 55$ \\
\hline \multirow[t]{2}{*}{ GROUP A vs B } & & $p=0.976057$ & \\
\hline & & & $6 / 55$ \\
\hline Apical segment prolapse & $3 / 77$ & & $1 / 55$ \\
\hline | and || degree prolapse & $3 / 77$ & & $5 / 55$ \\
\hline III and IV degree prolapse & $0 / 77$ & & \\
\hline \multirow[t]{2}{*}{ GROUP A vs B } & & $p=0.115037$ & \\
\hline & & & $5 / 55$ \\
\hline Posterior prolapse & $10 / 77$ & & $5 / 55$ \\
\hline | and || degree prolapse & $10 / 77$ & & $0 / 55$ \\
\hline III and IV degree prolapse & $0 / 77$ & & \\
\hline GROUP A vs B & & $p=0.486834$ & \\
\hline
\end{tabular}


$5 \%$ develop frequent recurrent episodes (15). The prevailing view regarding the pathogenesis of recurrent vulvovaginal candidiasis is that repeated episodes are not the result of more frequent introduction of the organism into the lower genital tract or infection with a more virulent organism but, rather, differences in host susceptibility factors (16).

Prevalence studies indicate that $10 \%$ to $55 \%$ of healthy women who are completely asymptomatic have vaginal cultures positive for Candida albicans $(17,18)$. In asymptomatic women with and without a history of recurrent vulvoaginal candidiasis, Candida was detected in vaginal samples in $29.4 \%$ of patients tested. (15).

These studies correspond with the results of our research and confirm that women may develop different genital infections in their urethra and/or vagina in the absence of symptoms.

Genitourinary prolapse can determine urinary incontinence or urinary retention caused by dislocation of the urethra and the bladder.

Severe genital prolapse is the most common cause of obstruction in females. Prolapse can affect bladder function in two ways: mechanically obstructing the urethra, dissipating the effect of the abdominal pressure on the urethra, and masking urinary incontinence (19).

The high incidence of urinary symptoms in women with severe genitourinary prolapse reported by some authors $(20,21)$ might be explained by obstructed micturition

A significant increase in urethral closure pressure (22), a higher detrusor pressure at maximun flow and maximum detrusor pressure $(23,24)$, uninhibited detrusor contractions discovered in $41 \%$ of patients (21), suggest that a severe genitourinary prolapse may produce obstructive symptoms very similar to the symptoms of men with IPB. We cannot draw conclusions from our study regarding the effects of high degree prolapses on micturition because of the small number of cases observed, all contained in the central group. The lower degree prolapses, however, did not show any significant statistical difference.

The most important factor in our study was, however, the age of patients.

In group A patients were older than in group $B$, with a significant statistical difference.

Lower urinary tract symptoms are common in older men and women $(25,26,27)$ but they are not a uniform disease entity (28).

Liv et al. (25) observed that the increasing occurence of nocturia was age-related and significantly higher in older than in younger patients.

Even in the absence of pathological conditions, the lower urinary tract changes as the individual ages. Detrusor contractility as well as bladder capacity and the ability to postpone voiding decline in both sexes, whereas urinary flow decreases with age.

Urinary output at night is also increased even in the absence of congestive heart failure. Increased nighttime urinary output in association with sleep disorders that are common in the elderly result in a normal pattern of 1 or 2 episodes of nocturia in the majority of healthy individuals in this age group (29).

Hypoestrogenism in the menopausal woman has a role in irritative urinary and local vaginal symptoms and they are quite amendable to estrogen therapy (30).
GROUP A 77

$\mathrm{N}^{\circ}$

Age
65.8
GROUP B 55 
Diseases of the cerebrospinal system, metabolic imbalances, detrusor degeneration (28) can all result in disabilities such as urinary incontinence, urgency, nocturia, frequency.

Many patients have lost control of the micturition reflex: the warning to void occurs suddenly and the abrupt sensation that urination is imminent cannot be controlled appropriately (28). Detrusor overactivity in the absence of outlet obstruction is common in the elderly (31). In some patients it is one sign of a neurological disorder (32). $80 \%$ of patients with cerebral cortical lesions show an overactive bladder (33).

It is a reasonable hypothesis that bladder overactivity primarily results from a disturbed central neuronal control of the lower urinary tract (34). The prevalence of an overactive bladder is constant up to the age of 65 .

$70 \%$ of these patients have a coordinated reflex micturition at normal bladder volumes, but an abnormal perception of bladder fullness and lack of voluntary inhibitory control. This constellation of symptoms and signs indicates a suprapontine dysfunction (34).

In so called "idiopathic bladder overactivity" the cause is less obvious. Ahlberg et al. (32) suggest that neuropathy might not be uncommon in this case, whereas Hampel et al. (35) consider bladder aging with bladder outlet obstruction and chronic bladder irritation as possible causes of non-neurogenic detrusor hyperactivity.

Andersen et al. (36) studied bladder function in 20 healthy elderly males without clinical evidence of organic neurological disease finding detrusor overactivity in $53 \%$ of men. He concluded that detrusor overactivity seems to be a common finding in these patients without, however, being able to confirm if subclinical degenerative lesions within the central nervous control of the micturition reflex alone or in conjunction with increased sensory input from the incipient obstructed bladder are responsible for the occurrence of detrusor overactivity.

Increasing incidence of lower urinary tract symptoms often derive from changes in the receptor profile of the aging bladder (35). Ageing with or without bladder obstruction probably causes partial cholinergic denervation of the detrusor with a subsequent upregulation of muscarinic receptor sensitivity leading to bladder hyperactivity (35).

The changes of the structural features of the detrusor are another possible cause of LUTS in the elderly patient.
A study to examine the ultrastructure of muscle cells, interstitium and nerves of the detrusor in 12 women and 3 men with detrusor overactivity by electron microscopy was performed by Elbadawi et al. (31). The symptoms of subjects were frequency, nocturia, urgency, urge and mixed incontinence and none had diabetes or a significant neurological deficit. A distinctive dysjunction structural pattern was identified in 15 detrusor biopsies. The dysjunction pattern was characterised by moderately widened intercellular spaces, scarce intermediate muscle cell junctions, abundant distinctive protrusion junctions and ultra-close cell abutments, and absence of profiles characteristic of enlarged hypertrophic cells. Protrusion junctions and abutments were proposed as a possible manifestation of a process of muscle cell de-differentiation associated with natural aging, as well as the mediator in overactive detrusor of electrical coupling of muscle cells, in lieu of their normal mechanical conpling curtailed by marked reduction of intermediate cell junctions.

On this basis a bipartite myogenic mechanism is proposed to account for the involuntary contractions allowing neurally triggered unitary voiding contractions in the overactive detrusor.

The results of these studies confirm the importance of patients' age at the onset of irritative symptoms of the lower urinary tract.

\section{CONCLUSIONS}

The results of this study confirm that ageing is very important in the development of lower urinary tract symptoms in women.

Even in the absence of pathological conditions, the lower urinary tract changes as the individual ages and symptoms increase.

Urethral and/or vaginal infections and pelvic floor disorders, however, appear not to have particular importance.

\section{REFERENCES AND RECOMENDED READING}

\section{( ${ }^{*}$ of special interest, ${ }^{* *}$ of outstanding interest)}

1. MURPHY, D.M.; CAFFERKEY, M.T.; FALKINER, F.R. y cols.: "Urinary tract infection in female patients-a survey in general practice in the Dublin area". Irish Med. J., 75: 240, 1982.

2. KUNIN, C.M.: "Detection, prevention and management of urinary tract infections". Fourth edition. Chapter 7, p. 341. Philadelphia: Lea and Fabiger, 1987. 
3. OSTERGARD, D.R.: "The urethral syndrome. In: Ostergard D.R. ed. Gynecologic urology and urodynamics". Baltimore: Williams \& Wilkins, 183-187. 1980.

4. CHATTOPADHYAY, B.: "Problems with diagnosis and antibiotic treatment of frequency and dysuria syndrome". Lancet, II: 393, 1985.

5. KAPLAN, W.E.; FIRLIT, C.F.; SCHOENBERG, H.W.: "The female urethral syndrome: external sphincter spasm as etiology". J. Urol., 124: 48, 1980.

6. O'DONNELL, R.P.: “Acute urethral syndrome in women”. N. Engl. J. Med., 303: 1531, 1980.

*7. ARYA, O.P.; TONG, C.Y.; HART, C.A. y cols.: "Is Mycoplasma hominis a vaginal pathogen?". Sex. Transm. Infect., 77: 58, 2001.

**8. STAMM, W.E.; RUNNING, K.; HALE, J. y cols. "Etiologic role of Mycoplasma hominis and Ureaplasma urealyticum in women with the Acute Urethral Syndrome”. Sex. Transm. Dis. 10: 318, 1983.

**9. BUMP, R.C.; COPELAND, W.E.: "Urethral isolation of the genital mycoplasmas and Chlamydia trachomatis in women with chronic urologic conplaints". Am. J. Obstet. Gynecol.,152: 38, 1985.

10. CALLERI, L.F.; TACCANI, C.; PORCELLI, A.: "Ureaplasma urealyticum vaginosis and premature rupture of membranes. What is its role?". Minerva Ginecol., 52: 49, 2000.

11. FARLEY, T.A.; COHEN, D.A.; ELKINS, W.: "Asymptomatic sexually transmitted diseases: the case for screening". Prev. Med., 36: 502, 2003.

*12. GILLESPIE, W.A.; HENDERSON, E.P.; LINTON, K.B. y cols.: "Microbiology of the Urethral (Frequency and Dysuria) Syndrome. A controlled study with 5 - year review". Br. J. Urol., 64: 270, 1989.

13. SHARMA, K.; AGGARWAL, A.; ARORA, U.: "Seroprevalence of Chlamydia trachomatis in women with bad obstetric history and infertility". Indian J. Med. Sci., 56: 216, 2002.

14. KENT, H.L.: "Epidemiology of vulvovaginitis". Am. J. Obstet. Gynecol., 165: 1168, 1991.

15. GIRALDO, P.; VON NOWASKONSKI, A.; GOMES, F.A.M. y cols.: "Vaginal colonization by Candida in asymptomatic women with and without a history of recurrent vulvovaginal candidiasis". Obstet \& Gynecol., 95: 413, 2000.

16. WITKIN, S.S.: "Immunologic factors influencing susceptibility to recurrent candidal vulvovaginitis". Clin. Obstet. Gynecol., 34 : 662, 1991.

*17. LINDNEN, G.E.M. ; PLANTEMA, F.H.F. ; HOOGKAMP-KORSTANJE, J.R.A.: "Quantative sudies of the vaginal flora of health women and of obstetrics and gynecological women”. J. Med. Microbiol., 11: 233, 1978.

*18. SOBEL, J.D.: "Candidal vaginitis". Clin. Obstet. Gynecol., 36: 153, 1993.

19. VIGNOLI, G.: "The role of urodynamics in preventing failures of anti-incontinece surgery; in Giberti C: Incidenza, prevenzione, trattamento delle complicanze e delle recidive della chirurgia della incontinenza urinaria da sforzo e del prolasso pelvico". Turin, Mi- nerva Medica, pp 9-13, 1989.

20. LONG, C.Y.; HSU S.C.; SUN, D.J. y cols.: “Abnormal clinical and urodynamic findings in women with severe genitourinary prolapse". Kaohsiung J. Med. Sci., 18: 593, 2002.

21. ROSENZWEIG, B.A.; PUSHKIN, S.; BLUMENFELD, D. y cols.: "Prevalence of abnormal urodynamic test results in continent women with severe genitourinary prolapse". Obstet. Gynecol., 79: 539, 1992.

22. RICHARDSON, D.A.; BENT, A.E.; OSTERGARD, D.R.: "The effect of uterovaginal prolapse on urethrovesical pressure dynamics”. Am. J. Obstet. Gynecol., 146: 901, 1983.

23. VECCHIOLI SCALDAZZA, C.: "Relation between volume of residual urine and urodynamic findings in women with cystourethrocele". Urol. Int., 68: 152, 2002.

24. WALL, L.L.; HEWITT, J.K.: "Urodynamic characteristics of women with complete post hysterectomy vaginal vault prolapse". Urology, 44: 336, 1994.

*25. LIN, T.L.; NG, S.C.; CHEN, Y.C. y cols.: "What affects the occurence of nocturia more: menopause or age?". Maturitas, 50: 71, 2005.

26. BRADWAY, C.: "Urinary incontinence among older women. Measurement of the effect on health-related quality of life". J. Gerontol. Nurs., 29: 13, 2003.

27. MOLANDER, U.; SUNDH, V.; STEEN, B.: "Urinary incontinence and related symptoms in older men and women studied longitudinally between 70 and 97 years of age. A population study". Arch. Gerontol. Geriatr., 35: 237, 2002.

**28. MELCHIOR, H.: "Disorders of bladder function in the elderly". Urologe A., 34: 329, 1995.

29. GOMES, C.M.; ARAP, S.; TRIGO-ROCHA, F.E.: "Voiding dysfunction and urodynamic abnormalities in elderly patients". Rev. Hosp. Clin. Fac. Med. S. Paulo, 59: 206, 2004.

30. LOVATSIS, D.; DRUTZ, H.P.: "The role of estrogen in female urinary incontinence and urogenital aging: a review”. Ostomy Wound Manage, 44: 48, 1998.

**31. ELBADAWI, A.; YALLA, S.V.; RESNICK, N.M.: "Structural basis of geriatric voiding dysfunction. III. Detrusor overactivity". J. Urol., 150: 1668, 1993.

32. AHLBERG, J.; EDLUND, C.; WIKKELSO, C. y cols.: "Neurological signs are common in patients with urodynamical verified "idiopathic" bladder overactivity”. Neurourol. Urodyn., 21: 65, 2002.

33. MURAYAMA, K.; KATSUMI, T.; IKEDA, M. y cols.: "Clinical study of voiding disorders in patients with cerebrovascular accidents". Hinyokika Kiyo, 37 : 1243, 1991.

34. GEIRSSON, G.; FALL, M.; LINDSTROM, S.: "Subtypes of overactive bladder in old age". Age Ageing. 22: 125,1993

**35. HAMPEL, C.; GILLITZER, R.; PAHERNIK, S. y cols.: "Epidemiology and aetiology of overactive bladder". Urologe A., 42: 776, 2003.

36. ANDERSEN, J.T.; JACOBSEN, O.; WORM-PETERSEN, J. y cols.: "Bladder function in healthy elderly males”. Scand. J. Urol. Nephrol.. 12: 123, 1978. 